\title{
PENGARUH PENGGUNAAN BAHAN SERBUK MARMER PADA STABILISASI TANAH LEMPUNG EKSPANSIF (Kasus Tanah Lempung Ekspansif di Daerah Citra Land Surabaya)
}

\author{
The Effect of Using Marble Powder in Stability of Expansive Clay \\ (Study Case of Expansive Clay in Citra Land Surabaya)
}

\author{
Ernawan Setyono ${ }^{1}$, Sunarto $^{2}$, Anggita Moro Gumilang ${ }^{3}$ \\ Jurusan Teknik Sipil-Fakultas Teknik-Universitas Muhammadiyah Malang \\ Kampus III Jl. Tlogomas No.246 Tlp. (0341) 464318 \\ Email: ernawan@umm.ac.id ; anggitamg18@gmail.com
}

\begin{abstract}
The construction of highway in expansive soil is generally found in Indonesia. This kind of soil will expand and can cause the structure or highway lifted when the water level is high. Whereas, when the condition of water contains was low, the expansive ground is able to wane and it inflicted of shrinkage. The impact of swelling and shrinkage activity, the road construction became unstable. Thus, it made longitudinal crack and bumpy in long term. One of the efforts to get the physical property of soil that is suitable with certain technique terms is soil stabilization method by using additional material. The material is called marble powder from the marble factory in Tulungagung, Jawa Timur. Unconfined Compression Test and California Bearing Ratio Test were used in this study. It was aimed to know the influence of adding marble powder on the strength and the value of density. The experimental object was made by compounding marble powder by 5\%, 10\%, 15\%, 20\% and 25\%. The outcome showed that expansive clay that stabilized with marble powder might repair physical and mechanism of soil. In soil physic test, clay soil in low plasticity level was collected as the sample. However, the compressive strength value and soil bearing capacity was increase after stabilized with marble powder.
\end{abstract}

Keywords: California Bearing Ratio (CBR), Independent compressive strength, Marble powder, Plasticity index, Soil stabilization.

\begin{abstract}
Abstrak
Konstruksi jalan diatas tanah dasar yang bersifat ekspansif banyak dijumpai di Indonesia. Jenis tanah ini akan mengembang dan dapat menyebabkan jalan atau struktur terangkat disaat kondisi kadar air tinggi. Sebaliknya disaat kadar airnya rendah, tanah ekspansif akan menyusut dan dapat menyebabkan penurunan jalan (shrinkage). Akibat perubahan muai susut (swelling and shrinkage activity) kontruksi jalan menjadi tidak stabil sehingga untuk jangka waktu yang lama terjadi keretakan memanjang dan bergelombang. Salah satu upaya untuk mendapatkan sifat tanah yang memenuhi syarat teknis tertentu adalah dengan metode stabilisasi tanah menggunakan bahan tambah serbuk marmer dari hasil olahan pabrik marmer di Tulungagung, Jawa Timur. Untuk mengetahui pengaruh penambahan serbuk marmer terhadap kekuatan dan nilai daya dukung tanah dibuktikan dengan pengujian Unconfined Compression Test dan uji California Bearing Ratio. Benda uji dibuat dengan variasi penambahan serbuk marmer sebesar $5 \%, 10 \%, 15 \%, 20 \%, 25 \%$. Dari pengujian menunjukkan bahwa tanah lempung ekspansif yang distabilisasi dengan serbuk marmer dapat memperbaiki sifat fisik dan mekanik tanah. Pada uji sifat fisik tanah sampel yang diambil termasuk tanah lempung dengan tingkat plastisitas rendah. Sedangkan nilai kuat tekan dan daya dukung tanah meningkat setelah distabilisasi dengan serbuk marmer.
\end{abstract}

Kata Kunci: California Bearing Ratio (CBR), Indeks plastisitas, Kuat tekan bebas, Serbuk marmer, Stabilisasi tanah.

\section{PENDAHULUAN}

Tanah lempung ekspansif adalah material tanah yang sensitif terhadap perubahan kadar air. Tentunya hal ini menimbulkan masalah pada konstruksi karena volume tanahnya berubahubah. Konstruksi jalan diatas tanah dasar yang bersifat ekspansif banyak dijumpai di 
Indonesia. Jenis tanah ini akan mengembang dan dapat menyebabkan jalan atau struktur terangkat disaat kondisi kadar air tinggi. Sebaliknya disaat kadar airnya rendah, tanah ekspansif akan menyusut dan dapat menyebabkan penurunan jalan (shrinkage). Akibat perubahan muai susut (swelling and shrinkage activity) kontruksi jalan menjadi tidak stabil sehingga untuk jangka waktu yang lama terjadi keretakan memanjang dan bergelombang. Lempung ekspansif adalah tanah yang mempunyai sifat kembang susut yang besar, sifat kembang susut ini sangat dipengaruhi oleh kandungan air yang ada di dalam tanah tersebut. Jika kandungan air dalam tanah cukup banyak maka tanah tersebut akan mengembang dan kekuatan daya dukungnya akan berkurang. Demikian sebaliknya, jika kadar airnya berkurang atau kering maka tanah itu akan menyusut dan mengakibatkan tanah pecah-pecah di permukaannya sedangkan daya dukungnya akan meningkat (Seta, 2010). Salah satu upaya untuk mendapatkan sifat tanah yang memenuhi syarat-syarat teknis tertentu adalah dengan metode stabilisasi tanah. Stabilitas tanah ekspansif yang murah dan efektif adalah dengan menambahkan bahan kimia tertentu, dengan penambahan bahan kimia dapat mengikat mineral lempung menjadi padat, sehingga mengurangi kembang susut tanah lempung ekspansif (Ingles dan Metcalf, 1972, dalam Sudjianto, 2015). Bahan-bahan untuk stabilisasi tanah lempung ekspansif yang saat ini sering digunakan masih diimpor dan harganya relatif mahal. Dengan mempertimbangkan biaya yang relatif mahal tersebut maka sangat perlu untuk dicoba alternatif lain yang lebih murah misalnya penggunaan bahan campuran serbuk marmer sebagai pengganti kapur sebagai perkuatan tanah. Menurut Hardiyatmo (2013), stabilisasi tanah dengan menggunakan bahan tambah kapur pada dasarnya sama dengan stabilisasi tanah dengan semen. Perbedaannya adalah kapur lebih cocok untuk stabilisasi tanah untuk tanah lempungan.

\section{Karakteristik Tanah Ekspansif}

Potensi mengembang tanah ekspansif sangat erat hubungannya dengan indeks plastisitas sehingga Chen membuat klasifikasi potensi pengembangan pada tanah lempung berdasarkan indeks plastisitas (IP) seperti yang tercantum dalam Tabel 1 (Chen, 1975, dalam Hardiyati, 2003).

Tabel 1. Hubungan Lempung Ekspansif dengan Indeks Plastisitas (Chen, 1975).

\begin{tabular}{lll}
\hline \multicolumn{1}{c}{ Potensi mengembang } & $\begin{array}{l}\text { Indeks } \\
\text {,IP }(\%)\end{array}$ & Plastisitas \\
\hline Rendah & $0-15$ \\
Sedang & $10-35$ \\
Tinggi & $20-55$ \\
Sangat tinggi & $>35$ \\
\hline
\end{tabular}

Menurut sistem klasisifikasi tanah dengan USCS, tanah lempung ekspansif memiliki batas cair (LL) > 50\% dan indeks plastisitas (IP) $>30 \%$ dengan simbol $\mathrm{CH}$ atau Clay with High Plasticity (plastisitas tinggi) seperti yang terlihat pada Gambar 1.

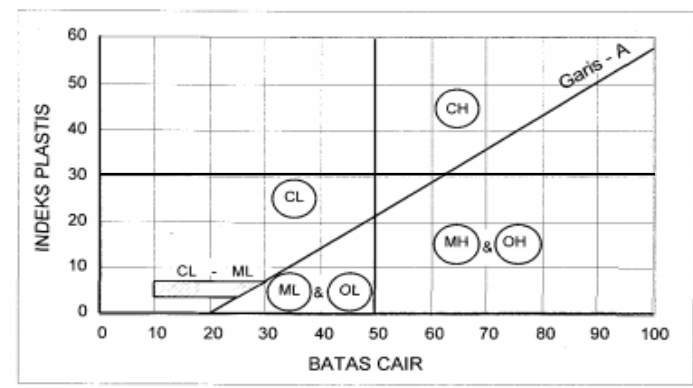

Gambar 1. Grafik Hubungan Batas Cair LL dan Indeks Plastisitas IP. (Sumber: Bowles)

\section{Identifikasi Tanah Ekspansif}

Identifikasi tanah ini sangat berhubungan dengan hasil pengujian dari laboratorium dan pengujian lapangan serta tingkat pengembangannya. Sudjianto (2007) melakukan identifikasi tanah lempung ekspansif yang ada di pulau jawa, lokasi identifikasi mulai dari wilayah Jawa Timur sampai dengan Jawa Barat identifikasi tersebut seperti pada Tabel 2.

\section{Sistem Klasifikasi Tanah}

Sistem klasifikasi tanah adalah sistem penggolongan yang diuraikan secara teratur dan logis dari jenis-jenis tanah yang mempunyai sifat-sifat yang sama ke dalam kelompok-kelompok dan sub kelompok berdasarkan pemakaiannya (Das,1995). Terdapat dua sistem klasifikasi yang sering digunakan yaitu USCS (Unified Soil Classification System) dan AASHTO 
(American Association of State Highway and Transportation Officials Classification). Sistem-sistem ini menggunakan sifat-sifat indeks tanah yang sederhana seperti distribusi ukuran butiran, batas cair, dan indeks plastisitasnya (Hardiyatmo,2010).

Tabel 2. Potensi Kembang Tanah Lempung Ekspansif di Pulau Jawa

\begin{tabular}{|c|c|c|c|c|c|c|}
\hline \multirow{2}{*}{ No } & \multirow{2}{*}{$\begin{array}{l}\text { Lokasi } \\
\text { Sampel }\end{array}$} & \multicolumn{4}{|c|}{ Batas Konsistensi Tanah } & \multirow[b]{2}{*}{$\begin{array}{l}\text { Potensi } \\
\text { Kembang }\end{array}$} \\
\hline & & $\begin{array}{l}\mathrm{LL} \\
(\%)\end{array}$ & $\begin{array}{l}\text { PL } \\
(\%)\end{array}$ & $\begin{array}{l}\text { SL } \\
(\%)\end{array}$ & $\begin{array}{l}\text { IP } \\
(\%)\end{array}$ & \\
\hline 1 & $\begin{array}{l}\text { Citra Land, } \\
\text { Surabaya } \\
\text { Mengganti, }\end{array}$ & 104,56 & 46,78 & 37,90 & 57,78 & Tinggi \\
\hline 2 & $\begin{array}{l}\text { Gresik } \\
\text { Dringu, }\end{array}$ & 55,00 & 19,20 & 11,56 & 35,80 & Sedang \\
\hline 3 & $\begin{array}{l}\text { Probolinggo } \\
\text { Mojowarno, }\end{array}$ & 66,75 & 35,25 & 16,15 & 31,50 & Sedang \\
\hline 4 & $\begin{array}{l}\text { Jombang } \\
\text { Caruban, }\end{array}$ & 79,24 & 41,65 & 12,30 & 37,59 & Sedang \\
\hline 5 & $\begin{array}{l}\text { Madiun } \\
\text { Saradan, }\end{array}$ & 72,00 & 24,00 & 15,50 & 48,00 & Tinggi \\
\hline 6 & $\begin{array}{l}\text { Nganjuk } \\
\text { Padangan, }\end{array}$ & 87,37 & 29,39 & 16,20 & 57,98 & Tinggi \\
\hline 7 & $\begin{array}{l}\text { Bojonegoro } \\
\text { Soko, }\end{array}$ & 85,00 & 30,00 & 9,06 & 55,00 & $\begin{array}{l}\text { Tinggi } \\
\text { Sangat }\end{array}$ \\
\hline 8 & $\begin{array}{l}\text { Ngawi } \\
\text { Tembalang }\end{array}$ & 101,00 & 29,77 & 10,70 & 71,23 & Tinggi \\
\hline 9 & $\begin{array}{l}\text {, Semarang } \\
\text { Purwodadi, }\end{array}$ & 87,50 & 21,55 & 15,15 & 59,95 & Tinggi \\
\hline 10 & $\begin{array}{l}\text { Grobongan } \\
\text { Pedan, }\end{array}$ & 89,17 & 37,16 & 15,10 & 51,15 & $\begin{array}{l}\text { Tinggi } \\
\text { Sangat }\end{array}$ \\
\hline 11 & $\begin{array}{l}\text { Klaten } \\
\text { Wates, }\end{array}$ & 91,30 & 29,55 & 14,10 & 61,75 & Tinggi \\
\hline 12 & $\begin{array}{l}\text { Jogjakarta } \\
\text { Bungursari, }\end{array}$ & 81,10 & 28,10 & 10,46 & 53,00 & $\begin{array}{l}\text { Tinggi } \\
\text { Sangat }\end{array}$ \\
\hline 13 & $\begin{array}{l}\text { Purwakarta } \\
\text { Dawuhan, }\end{array}$ & 96,20 & 22,35 & 25,90 & 73,85 & $\begin{array}{l}\text { Tinggi } \\
\text { Sangat }\end{array}$ \\
\hline 14 & $\begin{array}{l}\text { Subang } \\
\text { Cikampek, }\end{array}$ & 105,25 & 28,75 & 42,50 & 76,50 & Tinggi \\
\hline 15 & $\begin{array}{l}\text { Karawang } \\
\text { Ciwastra, }\end{array}$ & 63,17 & 27,52 & 15,10 & 35,65 & Tinggi \\
\hline 16 & Bandung & 99,10 & 31,65 & 18,55 & 67,45 & Tinggi \\
\hline
\end{tabular}

\section{Sistem klasifikasi tanah dengan USCS}

Dalam sistem ini, Cassagrande membagi tanah atas 3 (tiga) kelompok (Sukirman, 1992) yaitu :

1. Tanah berbutir kasar, $<50 \%$ lolos saringan No. 200.

2. Tanah berbutir halus, $>50 \%$ lolos saringan No. 200.

3. Tanah organik yang dapat dikenal dari warna, aroma, dan sisa-sisa tumbuhtumbuhan yang terkandung di dalamnya.
Tanah berbutir kasar adalah tanah yang mengandung 50 persen atau kurang butiran yang lolos saringan $0,075 \mathrm{~mm}$ (No. 200), sedangkan tanah berbutir halus adalah tanah yang mengandung lebih dari 50 persen butiran yang lolos saringan $0,075 \mathrm{~mm}$ (No.200). Lebih lanjut sistem unified membagi tanah menjadi 15 kelompok seperti pada Tabel 3.

\section{Tabel 3. Sistem Klasifikasi Tanah USCS}

\begin{tabular}{lccc}
\hline Jenis Tanah & Prefiks & Sub Kelompok & Sufiks \\
\hline \multirow{2}{*}{ Kerikil } & $\mathrm{G}$ & Gradasi Baik & $\mathrm{W}$ \\
& & Gradasi Buruk & $\mathrm{P}$ \\
Pasir & $\mathrm{S}$ & Berlanau & $\mathrm{M}$ \\
Lanau & $\mathrm{M}$ & Berlempung & $\mathrm{C}$ \\
Lempung & $\mathrm{C}$ & $\mathrm{wL}<50 \%$ & $\mathrm{~L}$ \\
Organik & $\mathrm{O}$ & $\mathrm{wL}>50 \%$ & $\mathrm{H}$ \\
Gambut & $\mathrm{Pt}$ & & \\
\hline
\end{tabular}

Tanah yang mengandung banyak bahan organik umumnya dapat dikenali melalui pengujian secara visual.

\section{Sistem klasifikasi tanah dengan AASHTO}

Tanah dibagi menjadi tujuh kelompok dimana tanah yang memiliki daya dukung dan karakteristik pelayanan hampir sama dimasukkan dalam satu kelompok. Ketujuh kelompok tersebut dinyatakan dengan A-1, A-2, A-3, A-4, A-5, A-6 dan A7. Secara umum, tanah yang paling baik untuk tanah dasar adalah A-1, sedangkan yang paling buruk adalah A-7. Dengan demikian, maka tebal perkerasan yang diperlukan akan makin meningkat sesuai dengan nomor kelas yang makin besar. Untuk klasifikasi lebih jelasnya dapat dilihat pada Tabel 4. 
Tabel 4. Sistem Klasifikasi Tanah AASHTO

Klasifikasi Umum Bahan-bahan berbutir (35\% atau kurang lolos No.200)

\begin{tabular}{|c|c|c|c|c|c|c|c|}
\hline \multirow{2}{*}{ Klasifikasi Kelompok } & \multicolumn{2}{|c|}{ A-1 } & \multirow[t]{2}{*}{ A-3 } & \multicolumn{4}{|c|}{ A-2 } \\
\hline & A-1a & $A-1 b$ & & A-2-4 & A-2-5 & \multirow[t]{2}{*}{ A-2-6 } & A-2-7 \\
\hline \multicolumn{7}{|l|}{$\begin{array}{c}\text { Analisis Saringan } \\
\text { Persen Lolos: }\end{array}$} & \\
\hline No.10 & $\leq 50$ & & & & & & \\
\hline No.40 & $\leq 30$ & $\leq 50$ & $\leq 51$ & & & & \\
\hline No.200 & $\leq 15$ & $\leq 25$ & $\leq 10$ & $\leq 35$ & $\leq 35$ & $\leq 35$ & $\leq 35$ \\
\hline \multicolumn{8}{|l|}{$\begin{array}{l}\text { Karakteristik fraksi } \\
\quad \text { lolos No.40 }\end{array}$} \\
\hline Batas Cair & & & & $\leq 40$ & $\leq 41$ & $\leq 40$ & $\leq 41$ \\
\hline Indeks Plastisitas & \multicolumn{2}{|c|}{$\leq 50$} & N.P & $\leq 10$ & $\leq 10$ & $\leq 11$ & $\leq 10$ \\
\hline Indeks Kelompok & \multicolumn{2}{|c|}{0} & 0 & \multicolumn{2}{|c|}{0} & \multicolumn{2}{|c|}{$\leq 4$} \\
\hline $\begin{array}{l}\text { Jenis-jenis bahan } \\
\text { pendukung utama }\end{array}$ & \multicolumn{2}{|c|}{$\begin{array}{l}\text { Fragmen batu kerikil } \\
\text { dan pasir }\end{array}$} & $\begin{array}{l}\text { Pasir } \\
\text { halus }\end{array}$ & \multicolumn{4}{|c|}{ Kerikil dan pasir berlanau atau berlempung } \\
\hline $\begin{array}{l}\text { Tingkatan umum } \\
\text { sebagai tanah dasar }\end{array}$ & \multicolumn{7}{|c|}{ Sangat baik sampai baik } \\
\hline Persen & lolos & & $\operatorname{lgan}$ & No. & 200 & & $35^{\circ}$ \\
\hline Klasifikasi Umum & $\begin{array}{l}\text { Tanah } \\
\text { Granuler }\end{array}$ & & $\operatorname{Tan}$ & Mengan & ung Lanau & empung & \\
\hline \multirow[t]{3}{*}{ Kelompok } & A-2 & & & A-5 & A-6 & A-7 & \\
\hline & A-2-7 & & & & & $A-7-5 b$ & $A-7-5 c$ \\
\hline & \multicolumn{7}{|c|}{ Persen lolos saringan } \\
\hline \multicolumn{8}{|l|}{ N.10 } \\
\hline \multicolumn{8}{|l|}{ No. 40} \\
\hline No.200 & $35 \max$ & & & 36 & $36 \min$ & 36 & $36 \mathrm{~min}$ \\
\hline Batas cair & $41 \mathrm{~min}$ & & & 41 & $40 \mathrm{~min}$ & 40 & $41 \mathrm{~min}$ \\
\hline Indeks Plastisitas & $11 \mathrm{~min}$ & & & 10 & $10 \mathrm{~min}$ & 10 & $11 \mathrm{~min}$ \\
\hline Fraksi Tanah & \multicolumn{3}{|c|}{ Kerikil, Pasir } & Lat & & \multicolumn{2}{|c|}{ Lempung } \\
\hline Kondisi Kuat & \multicolumn{3}{|c|}{ Sangat Baik } & \multicolumn{4}{|c|}{ Kurang baik hingga jelek } \\
\hline
\end{tabular}

* Persen lolos saringan No. $200>35 \%$

\section{Konsistensi Tanah Asli}

Konsistensi dapat diartikan sebagai sifat tanah yang menunjukkan kemudahan relatif untuk dirubah bentuknya. Istilah tersebut biasa digunakan terhadap tanah berbutir halus. Cara lain untuk memperkirakan konsistensi adalah berdasarkan perilakunya apabila dimanipulasi dengan tangan. Pada Tabel 5 ditunjukkan konsistensi tanah kohesif asli berdasarkan beberapa parameter serta cara pengujian praktis. Untuk menunjukkan karakteristi kondisi khusus yang dipandang penting, mungkin perlu ditambah penjelasan (deskripsi) sebagaimana ditunjukkan pada Tabel 6. 
Tabel 5. Konsistensi tanah ekspansif asli dan cara pengujian praktis

\begin{tabular}{|c|c|c|c|}
\hline KONSISTENSI & $\begin{array}{l}\text { KUAT TEKAN } \\
\text { BEBAS }\left(\mathrm{kg} / \mathrm{cm}^{2}\right)\end{array}$ & $\begin{array}{c}\text { PENETRASI } \\
\text { (TUMBUKAN/ft) }\end{array}$ & PENGUJIAN PRAKTIS \\
\hline $\begin{array}{l}\text { Sangat lunak } \\
\text { (very soft) }\end{array}$ & $<0,27$ & $0-1$ & $\begin{array}{l}\text { Contoh (tinggi }=2 \mathrm{x} \text { diameter) melorot akibat } \\
\text { berat sendiri. } \\
\text { Mudah ditembus kepal. }\end{array}$ \\
\hline Lunak (soft) & $0,27-0,55$ & $2-4$ & $\begin{array}{l}\text { Mudah dicuil dengan ibu jari dan telunjuk. } \\
\text { Mudah ditembus beberapa cm dengan ibu jari. }\end{array}$ \\
\hline $\begin{array}{l}\text { Teguh (medium } \\
\quad \text { firm) }\end{array}$ & $0,55-1,09$ & $5-8$ & $\begin{array}{l}\text { Mudah digores oleh jari, atau } \\
\text { Mudah ditembus ibu jari yang diberi kekuatan } \\
\text { moderat. }\end{array}$ \\
\hline Kokoh (stiff) & $1,09-2,19$ & $9-15$ & $\begin{array}{l}\text { Dapat digores jari, tapi dengan tenaga cukup besar. } \\
\text { Dapat ditembusdengan ibu jari, tapi dengan tenaga } \\
\text { besar. }\end{array}$ \\
\hline $\begin{array}{l}\text { Sangat kokoh } \\
\text { (very stiff) }\end{array}$ & $2,19-4,38$ & $16-30$ & $\begin{array}{l}\text { Sulit digores dengan jari. } \\
\text { Dapat ditembus dengan kuku. } \\
\text { Tidak dapat digores jari. }\end{array}$ \\
\hline Keras (hard) & $>4,38$ & $>30$ & Dapat digores kuku ibu jari denqan susah. \\
\hline
\end{tabular}

*Sumber: Krebs, 1971, dalam DPU No. 003 - 01/BM/2006

Tabel 6. Deskripsi khusus untuk konsistensi tanah berbutir halus

\begin{tabular}{ll}
\hline \multicolumn{1}{c}{ DESKRIPSI } & \multicolumn{1}{c}{ KONDISI TANAH } \\
\hline Rapuh (brittle) & Runtuh dengan sedikit deformasi. \\
& Merupakan karakteristik tanah tersementasi. \\
& Sangat keras; tersementasi sangat kuat; tidak lunak melalui pembasahan \\
Sangat keras (indurated) & lama. \\
& Membentuk lapisan dan disebut harapan. \\
& Pada keadaan lembab, mudah dihancurkan ibu jari dan telunjuk dengan \\
& kekuatan lemah sampai moderat dan menyatu kembali bila ditekan \\
& bersama; bila kering, mudah dijadikan serbuk atau dihancurkan dengan \\
& tangan. \\
Mudah hancur (friable) & Sering berlaku pada tanah kohesif yang lekatannya kurang, bersifat \\
& seperti mika, atau mempunyai gugus struktur yang terbentuk akibat \\
& sementasi lemah dengan bahan organik. \\
& Bila beban dilepas, mudah melendut balik (rebound); kembali ke \\
bentuk asal setelah dilendutkan kecil. \\
Elastis (elastic) & Merupakan karakteristik lanau dengan kandungan tinggi kimika. \\
& Porus, lepas-lepas dan elastis, mempunyai kandungan tinggi bahan \\
Keropos (spongy) & organik dan bahan berserat.
\end{tabular}

*Sumber: Krebs, 1971, dalam DPU No. 003 - 01/BM/2006

\section{Stabilisasi Tanah}

Pengertian stabilisasi adalah pencampuran tanah dengan bahan tertentu guna memperbaiki sifat-sifat teknis tanah, atau dapat pula stabilisasi tanah adalah usaha untuk merubah atau memperbaiki sifat-sifat teknis tanah agar memenuhi syarat teknis tertentu. Proses stabilisasi tanah meliputi pencampuran tanah dengan tanah lain untuk memeproleh gradasi yang dinginkan, atau pencampuran tanah dengan bahan tambah buatan pabrik, sehingga sifat-sifat teknis tanah menjadi lebih baik. Metode stabilisasi tanah yang sering digunakan adalah stabilisasi kimia, fisik, termal, dan mekanis (Bowles, 1984). Mengapa tanah harus di stabilisasi? Tanah merupakan salah satu material yang memegang peranan penting dalam Konstruksi atau Pondasi, sehingga 
mutlak diperlukan pengetahuan tentang tanah dengan sifat-sifat teknis yang memadai.

\section{Serbuk Marmer}

Hasil penelitian PT. Sucofindo Jakarta menyebutkan bahwa komposisi yang terkandung dalam limbah marmer adalah senyawa $\mathrm{CaO}$ dengan kadar 52.69\%, $\mathrm{CaCO} 3$ $41.92 \%, \mathrm{MgO} 0.84 \%$, $\mathrm{MgCO} 31.76 \%$, $\mathrm{SiO} 21.62 \%, \mathrm{Al} 2 \mathrm{O} 3+\mathrm{Fe} 2 \mathrm{O} 30.37 \%$, dari hasil ini terlihat komposisi utama limbah marmer adalah zat kapur (Subekti, 2007, jurnal penelitian Harianto dan Masri 2016). Sebagai bahan stabilisasi untuk tanah mengembang, yakni serbuk marmer di Jawa Timur banyak didapat sebagai hasil buangan (limbah) dari pabrik pengolahan/pemotongan marmer. Saat ini limbah serbuk marmer dijual dipasaran dengan harga berkisar antara Rp.25,-s/d Rp.35,-per kg, sangat murah bila dibandingkan harga kapur antara Rp.100,-a/d Rp.125,- per kg. Jadi besar kemungkinan bahwa stabilisasi tanah dengan serbuk marmer akan menjadi salah satu alternatif yang murah, apalagi didukung dengan keberadaan sedikitnya 3 (tiga) pabrik pengolahan marmer yang besar di Jawa Timur dan banyaknya pusat-pusat kerajinan marmer rumah tangga/desa di daerah Tulungagung. Jadi pasokan serbuk marmer relatif cukup banyak dari limbah tempattempat pengolahan tersebut. Pada dasarnya marmer mempunyai unsur dominan yang sama dengan kapur.

\section{METODE PENELITIAN}

Metode yang digunakan dalam penelitian ini merupakan metode penelitian dengan pengujian laboratorium yang dilakukan di Laboratorium Mekanika Tanah, Jurusan Teknik Sipil, Fakultas Teknik, Universitas Muhammadiyah Malang. Tanah yang digunakan dalam penelitian ini adalah tanah lempung ekspansif dari lokasi daerah Citra Land Surabaya. Pada penelitian ini bahan campuran yang ditambahkan adalah bahan serbuk marmer. Metodologi dan prosedur penelitian dibagi menjadi dua tahap, yaitu pengujian sifat fisis tanah (uji karakteristik tanah lempung ekspansif) dan pengujian sifat mekanis tanah. Adapun diagram alir penelitian adalah seperti pada Gambar 2.

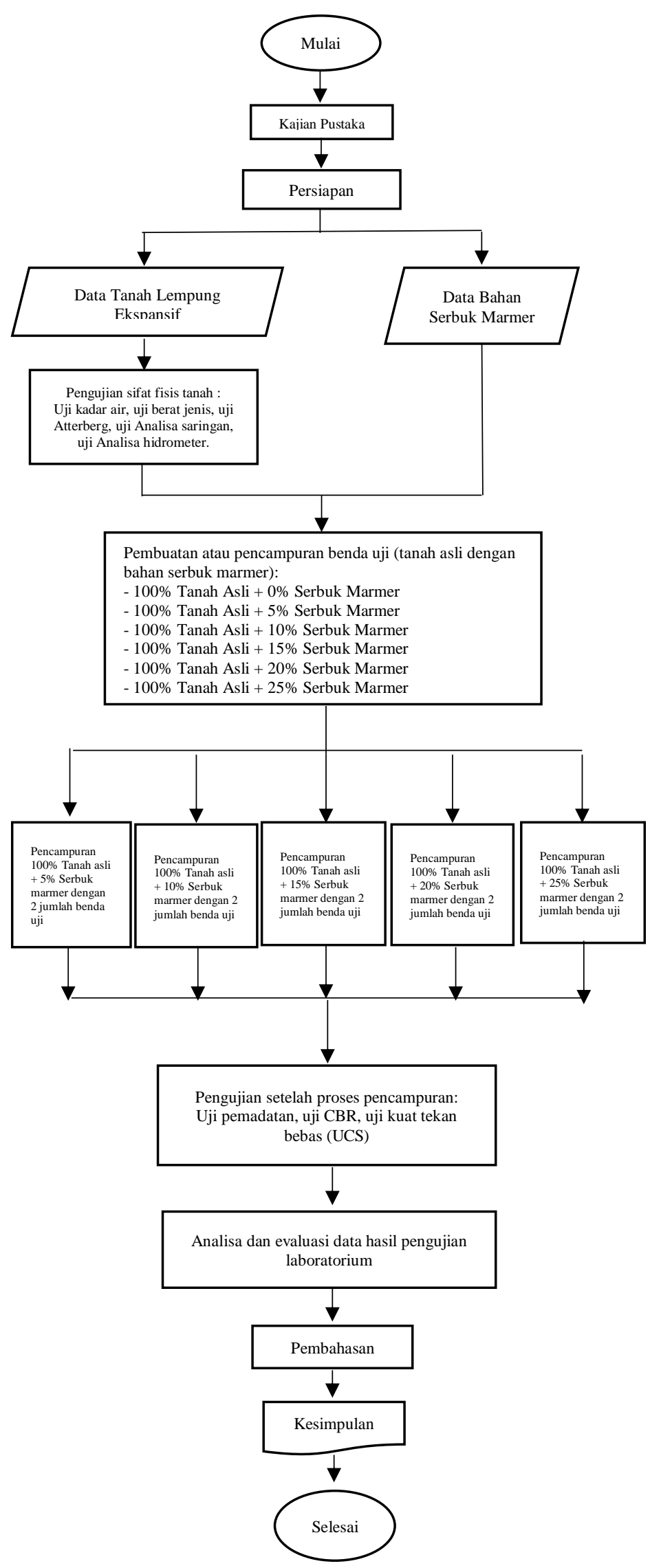

Gambar 2. Diagram Alir

Penelitian 


\section{HASIL DAN PEMBAHASAN}

\section{Karakteristik Tanah Asli}

Dari hasil pengujian karakteristik tanah di laboratorium maka diperoleh datadata sifat fisis tanah pada Tabel 7.

Tabel 7. Rekapitulasi Hasil Pemeriksaan Karakteristik Tanah Asli

\begin{tabular}{|c|c|c|}
\hline No. & Jenis Pemeriksaan & $\begin{array}{c}\text { Hasil } \\
\text { Pengujian }\end{array}$ \\
\hline 1 & $\begin{array}{l}\text { Pengujian Kadar Air } \\
(\omega)\end{array}$ & $52.90 \%$ \\
\hline 2 & Pengujian Berat Jenis & $2.70 \mathrm{gr} / \mathrm{cm}^{3}$ \\
\hline 3 & Pengujian Berat Isi & \\
\hline 4 & a. Derajat Kejenuhan & $84.01 \%$ \\
\hline 5 & b. Angka Pori & 1.39 \\
\hline 6 & Batas-batas Konsistensi & \\
\hline 7 & a. Batas Cair (LL) & $72.51 \%$ \\
\hline 8 & b. Batas Plastis (PL) & $32.68 \%$ \\
\hline 9 & c. Indeks Plastisitas (PI) & $39.83 \%$ \\
\hline 10 & Kuat Tekan Bebas (qu) & $\begin{array}{c}0.866 \\
\mathrm{~kg} / \mathrm{cm}^{2}\end{array}$ \\
\hline 11 & Pemadatan & \\
\hline 12 & $\begin{array}{l}\text { a. Berat Isi Kering } \\
\text { Maksimum }(\gamma d \text { max })\end{array}$ & $1.32 \mathrm{gr} / \mathrm{cm}^{3}$ \\
\hline 13 & $\begin{array}{l}\text { b. Kadar Air Optimum } \\
\text { ( } \omega \text { optimum })\end{array}$ & $32 \%$ \\
\hline 14 & Pengujian CBR & $2.79 \%$ \\
\hline
\end{tabular}

karakteristik tanah diatas, menunjukkan bahwa kadar air yang terkandung pada tanah adalah sebesar 52,90\%. Dimana kadar air didefinisikan sebagai perbandingan berat air yang terkandung dalam tanah dengan butiran kering dari volume tanah yang diselidiki. Kemudian dari hasil pemeriksaan berat jenis tanah menghasilkan berat jenis (Gs) sebesar $2.70 \mathrm{gr} / \mathrm{cm}^{3}$, yang dimana berat spesifik untuk tanah berlempung tak organik harga tersebut berkisar antara 2,68 $-2,75 \mathrm{gr} / \mathrm{cm}^{3}$. Melihat nilai angka pori maka tanah termasuk dalam jenis lempung lembek (soft clay) dengan batas nilai angka pori antara 0,9 - 1,4. Dari hasil pemeriksaan Atterberg limit menghasilkan nilai kadar air untuk batas cair (LL) sebesar 72,51\%, batas plastis (PL) sebesar 32,68\%, dan indeks plastisitas (PI) sebesar $39,83 \%$, serta dari hasil pemlotan grafik sistem klasifikasi tanah dapat diidentifikasikan bahwa tanah yang diuji adalah tanah lempung anorganik dengan plastisitas tinggi atau High Plasticity Clay $(\mathrm{CH})$. Dilihat dari hasil pengujian pemadatan dapat dijelaskan bahwa ditemukan kadar air optimum dengan nilai $32 \%$ dan kepadatan kering optimum $1,32 \mathrm{gr} / \mathrm{cm}^{3}$.

\section{Pemeriksaan Atterberg \\ Penambahan Serbuk Marmer}

dengan

Data dari hasil pengujian Atterberg

Limit ini akan disajikan pada Tabel 8.

Tabel 8. Nilai Atterberg dengan Campuran Kadar Serbuk Marmer

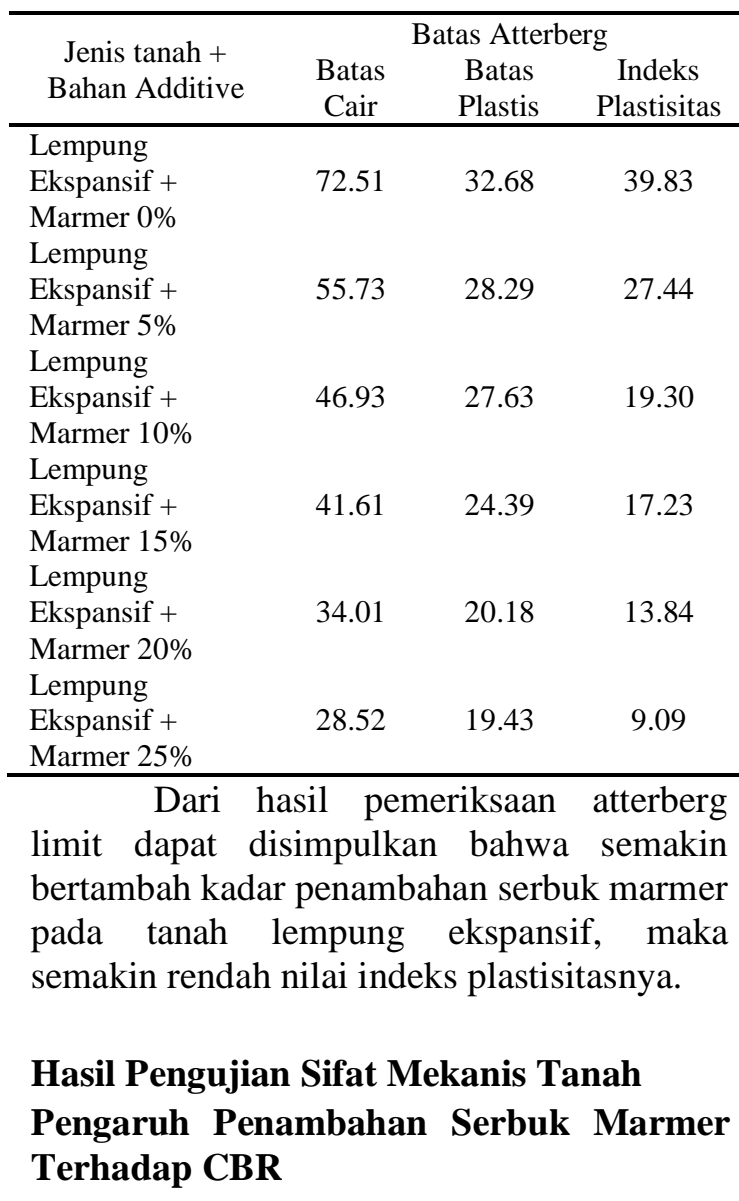

Hasil pengujian CBR dapat dilihat pada Tabel 9 dan grafik pada Gambar 3.

Tabel 9. Hasil Uji CBR dengan Variasi Penambahan Serbuk Marmer

\begin{tabular}{clcc}
\hline \multirow{2}{*}{ No. } & \multicolumn{2}{c}{ Variasi Campuran } & \multicolumn{2}{c}{ Nilai CBR } \\
& \multicolumn{2}{c}{$0.1^{\prime \prime}$} & $0.2^{\prime \prime}$ \\
\hline 1 & $\begin{array}{l}\text { 100\% Tanah Asli } \\
\text { 100\% Tanah }\end{array}$ & 2.090 & 2.787 \\
2 & $\begin{array}{l}\text { Asli+5\% Marmer } \\
\text { 100\% Tanah }\end{array}$ & 3.035 & 3.327 \\
3 & $\begin{array}{l}\text { Asli+10\% Marmer } \\
\text { 100\% Tanah }\end{array}$ & 3.844 & 4.001 \\
4 & $\begin{array}{l}\text { Asli+15\% Marmer } \\
\text { 100\% Tanah }\end{array}$ & 4.653 & 4.765 \\
5 & $\begin{array}{l}\text { Asli+20\% Marmer } \\
\text { 100\% Tanah }\end{array}$ & 5.462 & 5.574 \\
6 & Asli+25\% Marmer & 6.339 & 6.474 \\
\hline
\end{tabular}




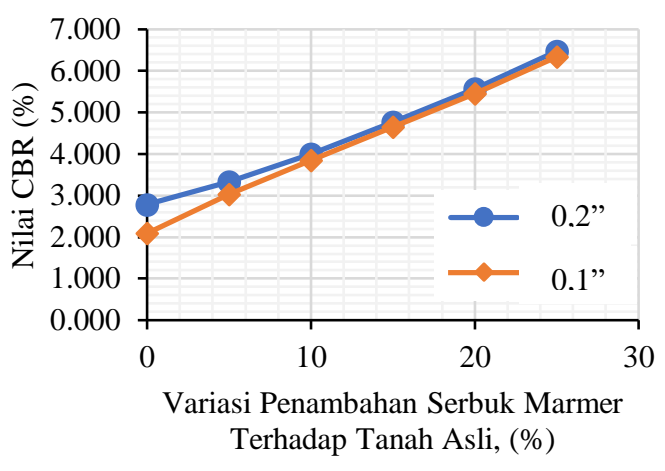

Gambar 3. Grafik Hubungan Penambahan Serbuk Marmer dengan Nilai CBR

Dari data di atas terlihat nilai CBR yang terus meningkat, dari yang semula pada penambahan $5 \%$ serbuk marmer nilai CBR 2,787 , sampai pada penambahan $25 \%$ serbuk marmer nilai CBR terus meningkat menjadi 6,474 .

\section{Pengaruh Penambahan Serbuk Marmer Terhadap UCT}

Hasil rekapitulasi pengujian UCT terhadap tanah kembang susut yang distabilisasi dengan limbah serbuk marmer dapat dilihat pada Tabel 10 dan grafik pada Gambar 4.

Tabel 8. Hasil Uji UCT dengan Variasi Penambahan Serbuk Marmer

\begin{tabular}{clc}
\hline No. & \multicolumn{1}{c}{ Variasi Campuran } & $\begin{array}{c}\text { Nilai qu } \\
\left(\mathrm{kg} / \mathrm{cm}^{2}\right)\end{array}$ \\
\hline 1 & 100\% Tanah Asli & 0.866 \\
2 & $\begin{array}{l}\text { 100\% Tanah Asli }+5 \% \\
\text { Marmer }\end{array}$ & 0.888 \\
3 & $\begin{array}{l}\text { 100\% Tanah Asli }+10 \% \\
\text { Marmer }\end{array}$ & 1.078 \\
4 & $\begin{array}{l}\text { 100\% Tanah Asli }+15 \% \\
\text { Marmer }\end{array}$ & 1.354 \\
5 & $\begin{array}{l}\text { 100\% Tanah Asli }+20 \% \\
\text { Marmer }\end{array}$ & 1.598 \\
6 & $\begin{array}{l}\text { 100\% Tanah Asli }+25 \% \\
\text { Marmer }\end{array}$ & 1.734 \\
\hline
\end{tabular}

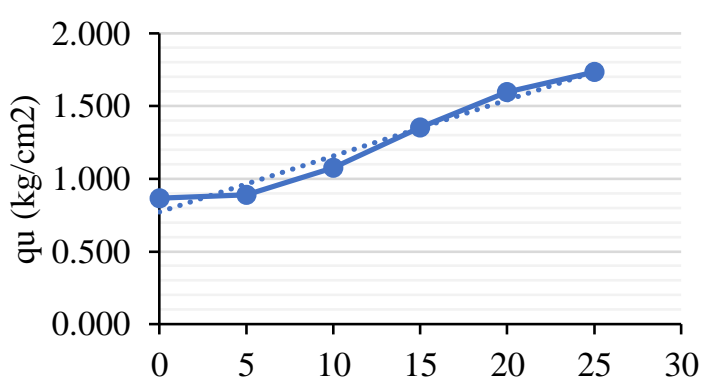

Presentase Penambahan Marmer (\%)

Gambar 4. Grafik Hubungan Penambahan

Serbuk Marmer dengan Nilai qu

Tabel 8 dan Gambar 4 yang ditunjukkan di atas menjelaskan bahwa pengujian kuat tekan bebas dengan menggunakan variasi penambahan serbuk marmer $0 \%$ sampai dengan $25 \%$ terus mengalami peningkatan hingga pada puncak penambahan $25 \%$ serbuk marmer dengan nilai qu sebesar $1,734 \mathrm{~kg} / \mathrm{cm}^{2}$ dari nilai qu tanah asli sebesar $0,866 \mathrm{~kg} / \mathrm{cm}^{2}$.

\section{KESIMPULAN}

Dari hasil pemeriksaan sifat fisis tanah yang telah dilakukan diperoleh hasil yang menunjukkan bahwa tanah yang digunakan pada penelitian ini memiliki potensi kembang susut yang tinggi. Maka dengan pengujian batasbatas konsistensi tanah sampai dengan penambahan kadar 25\% serbuk marmer telah menghasilkan nilai indeks plastisitas rendah sebesar $9,09 \%$.

Setelah dilakukan penambahan serbuk marmer pada tanah asli diperoleh hasil yang menunjukkan bahwa semakin bertambah jumlah campuran serbuk marmer maka semakin naik nilai CBR karena terjadi proses sementasi akibat penambahan kadar serbuk marmer. Rongga-rongga pori pada tanah akan dikelilingi bahan sementasi yang lebih keras, daya ikat antar butiran menyebabkan butiran tanah kembang susut ini menjadi lebih besar sehingga nilai CBR mengalami kenaikan dari nilai awal 2,787\% kemudian naik menjadi $6,474 \%$ pada variasi penambahan ke $25 \%$ serbuk marmer. 
Melalui pengujian kuat tekan bebas (UCT), kekuatan tanah mengalami kenaikan seiring dengan penambahan kadar serbuk marmer dari yang semula $0,866 \mathrm{~kg} / \mathrm{cm}^{2}$ naik menjadi $1,734 \mathrm{~kg} / \mathrm{cm}^{2}$ pada penambahan kadar serbuk marmer $25 \%$.

\section{DAFTAR PUSTAKA}

Bowles, Joseph E. (1984). Sifat-sifat Fisis Dan Geoteknis Tanah, Jakarta: Erlangga.

Das, Braja M. (1985). Mekanika Tanah Jilid 1, Jakarta: Erlangga.

Departemen Pekerjaan Umum, Nomor 003 01/BM/2006, Pekerjaan Tanah Dasar.

Hardiyati, S. (2003). Studi Potensi Mengembang Kekuatan Tanah Lempung Ekspansif Dengan Dan Tanpa Kapur Akibat Siklus Berulang Basah-Kering, Tesis. Universitas Diponegoro Semarang.

Hardiyatmo, Hary Christady. (2013). Stabilisasi Tanah Untuk Perkerasan Jalan. Yogyakarta: Gadjah Mada University Press.

Harianto, Tri., dan Masri, Ahmad. (2016). Karakteristik Mekanis Tanah Kembang Susut Yang Distabilisasi Dengan Limbah Marmer. Dalam Prosiding Seminar Nasional Teknik Sipil Universitas Muhammadiyah Surakarta, 2016, pp. 293-430.

Seta, Wijaya. (2010). Perilaku Tanah Ekspansif Yang Dicampur Dengan Pasir Untuk Subgrade, Master Tesis, Universitas Dipenogoro Semarang.

Sudjianto, Agus Tugas. (2015). Tanah Ekspansif, Yogyakarta: Graha Ilmu.

Sukirman, S. (1992). Perkerasan Lentur Jalan Raya, Bandung: Nova. 